\title{
Child Intoxication With Breast Implant Material Ingredients
}

National Cancer Institute

\section{Source}

National Cancer Institute. Child Intoxication With Breast Implant Material Ingredients. NCI Thesaurus. Code C50493.

Children affected by toxins may be due to silicone breast implants and their effects on unborn children and from breastfeeding. 